M. V. Chernyavskyy ${ }^{1}$, orcid.org/0000-0003-4225-4984, A.M. Voronov ${ }^{2}$, orcid.org/0000-0003-4538-7870, O.V. Moiseienko ${ }^{2}$, orcid.org/0000-0002-8081-6960, S.H. Duliienko ${ }^{1}$, orcid.org/0000-0002-2811-8882, T. M. Monastyriova ${ }^{1}$, orcid.org/0000-0001-8199-2416

\title{
PREDICTING CHANGES IN THE SULFUR CONTENT DURING STEAM COAL PREPARATION AND THE LEVEL OF SULFUR DIOXIDE EMISSIONS WHEN ITS COMBUSTION
}

Purpose. Development of a method and forecast estimation of sulfur dioxide emission reduction during combustion of steam coal by regulating its quality during coal preparation.

Methodology. Study on sulfur content in coal using sieve, fractional analysis, analysis of ash and total sulfur content. Forecasting of sulfur content in concentrate according to the developed calculation method. Production tests at the coal preparation plant. Forecasting of the level of $\mathrm{SO}_{2}$ emissions during pulverized coal combustion according to the developed calculation method.

Findings. The distribution of sulfur content of Ukrainian steam bituminous coal by size classes depending on ash content is investigated; the proximity of sulfur content to the linear dependance on the ash content of the run-of-mine coal, rock-free substance, rock and concentrate is proved. The calculations of the level of $\mathrm{SO}_{2}$ emissions during pulverized combustion of coal and its cleaned products taking into account their elemental composition is performed, and the linear dependence of the level of $\mathrm{SO}_{2}$ emissions on the total sulfur content to lower heating value (LHV) ratio is proved. Based on the obtained results, methods are developed for determining the expected sulfur content in the concentrate and the forecasted level of $\mathrm{SO}_{2}$ emissions during its combustion; the optimal depth of preparation for the coal from various mines is determined by the criterion of compliance of the $\mathrm{SO}_{2}$ emission level with the current environmental standards.

Originality. Proximity of the sulfur content to the linear dependence on the ash content of the run-of-mine coal, rock-free substance, rock and concentrate is proved. The linear dependence of the level of $\mathrm{SO}_{2}$ emissions on the ratio of the total sulfur content to LHV during pulverized combustion of coal and its clean products is proved.

Practical value. A method has been developed for determining the expected sulfur content in the products of coal preparation by jigging, taking into account the allowable content of the high-density fraction in the concentrate and adding dense slimes to the coal preparation products. A method has been developed for determining the predicted level of $\mathrm{SO}_{2}$ emissions during their combustion. The optimal depth of the coal preparation for coal from various mines has been determined by the criterion of compliance of the level of $\mathrm{SO}_{2}$ emissions with the current environmental standards.

Keywords: steam coal, sulfur content, coal preparation, pulverized combustion, sulfur dioxide emissions

Introduction. The basis of Ukraine's energy independence is domestically mined coal and coal-fired thermal power plants (TPPs), which provide a third of electricity generation. In conditions when nuclear power plants (NPPs) are able to carry only the base load, and droughts in recent years have reduced the regulatory capacity of hydropower plants, particularly pulverized coal power units of 12 large TPPs have remained the main tool for regulating the energy consumption schedule [1].

By signing an Association Agreement with the European Union in 2014, Ukraine has committed itself to implementing its environmental directives, including reducing sulfur dioxide emissions. The problem is that Ukrainian steam coal is mostly high-sulfur, and deep flue gas desulphurization units at TPPs have not been built yet. Therefore, the "National Emissions Reduction Plan for Large Combustion Plants" [2] states that before construction of desulfurization systems, which is planned for the second half of the 2020s, the standards in force until 2017 will be temporarily extended, and $\mathrm{SO}_{2}$ emissions will be gradually reduced by the use of fuel with low sulfur content. Therefore, the urgent task is to develop a method and forecast assessment of reducing emissions of sulfurous anhydride when steam coal combustion by regulating its quality during preparation. To do this, it is necessary to investigate the distribution and properties of sulfur inclusions in the fractions and size classes of coal, which are separated during coal preparation process.

(C) Chernyavskyy M.V., Voronov A. M., Moiseienko O.V., Duliienko S. H., Monastyriova T. M., 2021
Unsolved aspects of the problem. Sulfur in coal is contained in the form of various compounds that are a part of the organic and mineral matter of the fuel [3]. Sulfur-containing organic compounds include mercaptans, thioethers, thiophenols and cyclic thiophene derivatives [4]. Organic sulfur is evenly distributed over the coal substance, it cannot be extracted by mechanical methods $[5,6]$. Organic sulfur compounds compose approximately $0.3-0.5 \%$ of sulfur in coal. The range of organic sulfur content in Ukrainian coal is $0.3-0.5 \%$, but $2.5-3 \%$ also can appear; this indicates that organic sulfur was formed not only due to sulfur of the original plant material [7]. The source of the formation of secondary sulfur could be elemental sulfur, which interacted with organic matter under appropriate conditions and increased the amount of organic sulfur.

In the mineral matter, sulfur is found mainly in the form of sulfates (mainly calcium and iron) and iron disulfides $\mathrm{FeS}_{2}$, there is also elemental sulfur in small quantities [8]. Sulfate sulfur in coal is contained in small quantities, being more common in fuels that have long been stored on the surface. This is mainly the result of oxidation of pyrite, it exists in the form of thin plasters of gypsum (density $2300 \mathrm{~kg} / \mathrm{m}^{3}$ ). Elemental sulfur is distributed in the form of fine compounds. In coal, it is not more than $0.15 \%$. Iron disulfide is the main type of sulfur compounds in fuel. Forms of inclusions of iron disulfide (marcasite, density $4880 \mathrm{~kg} / \mathrm{m}^{3}$, and pyrite, density $4900-$ $5200 \mathrm{~kg} / \mathrm{m}^{3}$ ) in coal seams are different. The pyrite formed during coal accumulation is evenly distributed over the coal substance, and, as a rule, is bound to the organic mass, while 
the pyrite formed over the cracks of drying by infiltration after cessation of the coal accumulation process is distributed coarsely, in the form of lenses, grains, nests. These impurities can be removed mechanically [9].

To desulfurize coal, its division into fractions that differ in density, magnetic, electrostatic, flotation properties (physical methods), chemical treatment, bacterial leaching, and a combination of these methods is used.

Chemical methods based on the action of oxidizing and rarely reducing agents lead to the conversion of sulfur into products which are gaseous or soluble in aqueous media. For example, steam-air treatment of Donbas coal at $200-350{ }^{\circ} \mathrm{C}$ [10] converts $55 \%$ of the initial amount of sulfur into gaseous sulfur oxides (this method is somewhat common for coking coal, but it is not suitable for steam coal, because such treatment removes some volatile substances needed to ignite the pulverized coal flare) [11]. Under the action of aqueous solutions of oxidants (e.g., nitric acid), almost all inorganic and more than $70 \%$ of organic sulfur compounds are extracted from coal [11, 12]. A significant degree of desulfurization is achieved by bacteriological leaching of coal by chemo-autotrophic microorganisms - up to $90 \%$ of pyrite sulfur [13]. However, these methods are not used for steam coal due to their high cost (more than 50 USD per 1 ton of coal).

Physical methods provide a reduction of sulfur content by $10-60 \%$ in concentrates, mainly due to the removal of pyrite sulfur. The effectiveness of physical methods of coal desulfurization in preparation is determined by the nature of sulfur compounds in coal (the ratio of organic and inorganic sulfur compounds, the size of pyrite inclusions, and so on), and by the level of techniques and technology used in coal preparation plants (fineness of grinding, accuracy of separation, hardware design, and others).

Pyrite inclusions have a low magnetic susceptibility, which can increase sharply during heat treatment and oxidation as a result of structural changes and the formation of new compounds. High-gradient magnetic separation [14], as well as "magnetizing" treatment (high-speed steam-air heat treatment, heating in high-frequency and microwave fields, treatment with gaseous pentacarbonyl iron, and so on [15]), are used to separate fine pyrite inclusions from coal. Despite the high cost, this method is theoretically applicable in pulverizing systems of TPP boilers, where coal grinding and heating of pulverized coal are integrated into one technological process [16], but so far it is under investigation. On the other hand, the increased density of pyrite grains allows removing them from pulverized coal in separators of medium-speed mills due to a combination of inertial and gravitational forces [17]; this method is at the stage of technological tests.

Currently, the only one productionally common method for preparing coal for pulverized combustion is the gravity concentration (on concentration tables or mainly by jigging), in which most part of the rock is removed from coal, in which most part of the rock is removed from coal, as rock density (exceeds $1800 \mathrm{~kg} / \mathrm{m}^{3}$ ) is more than coal matter dense (less than $1500 \mathrm{~kg} / \mathrm{m}^{3}$ ). Along with the rock, a significant part of sulfurcontaining mineral compounds, the density of which is from 2300 to $5200 \mathrm{~kg} / \mathrm{m}^{3}$, is removed [18].

The studies $[5,19,20]$ provide the data of research studies on several hundred samples of bituminous and subbituminous coal from the USA with initial ash content less than 8-16\%. The samples were crushed to different maximum coarse sizes, each obtained sub-sample was separated in high-density liquids of different densities, and the yield, ash content and sulfur content in pop-up and submerged fractions were determined (example - in Fig. 1).

There was a general tendency to reduce the content of pyrite and total sulfur with decreasing ash content of sub-samples, and the decrease in ash content and sulfur content in the emerging fractions were stronger with a greater degree of coal crushing.

The work [22] studied Ukrainian steam coal - bituminous, semi-anthracite and anthracite - from Donbas and Lviv-Volyn
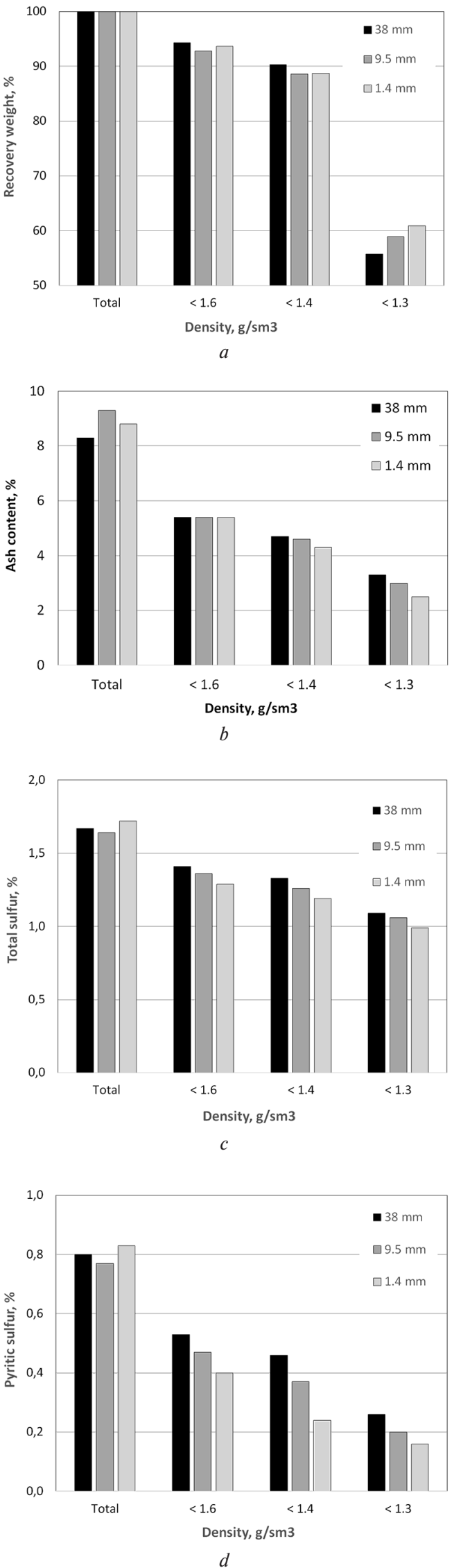

Fig. 1. An example of the characteristics of sub-samples of bituminous coal from the USA (Pennsylvania, Pittsburgh deposit) separated in high-dense liquids of different density [5]:

$a$-yield; $b$ - ash content; $c$ - total sulfur content $d$ - pyrite sulfur content 
basin. All samples were crushed to the same maximum coarse size of $3 \mathrm{~mm}$, but their high initial ash content determined a much wider range of density of high-dense liquids and, accordingly, the ash content range of emerging sub-samples. It was found that, depending on the ratio of mineral and organic sulfur content in the run-in-mine coal, the decrease in the ash content of sub-samples may be accompanied by both a decrease and an increase in the total sulfur content (Fig. 2).

For the general case, a linear dependence of the total sulfur content on the ash content of samples concentrated in a highdense liquid of different density was established in the form of

$$
S_{t}^{d}=S^{d a f} \cdot\left(100-A^{d}\right) / 100+S^{A} \cdot A^{d} / 100,
$$

where $S^{\text {daf }}$ is the proportion of sulfur in the dry ashless part of the coal; $S^{A}$ - in the ash part. The value of $S^{A}$ for different coals established in the experiments is from 0.2 to $5.5 \%$; for comparison, the same calculation for the sample bituminous coal from USA presented in Fig. 1 gives the value of $S^{A}$ from 8.2 to $9.6 \%$, which indicates to a lower average content of pyrite in the mineral part and a higher content of organic sulfur in the coal of Ukrainian deposits.

It should be noted that the above mentioned and other studies on changes in sulfur content during coal preparation were of a qualitative nature, performed in the laboratory and mostly (for a maximal particle size greater than $1 \mathrm{~mm}$ ) with static separation in a high-dense liquid. During the most common dynamic method in coal preparation - jigging - the removal of mineral grains depends on their density and size, which can vary widely. Therefore, the content of pyrite and sulfate sulfur in the mineral part of the run-of-mine coal, concentrate and wastes can vary significantly compared to static laboratory conditions. This is connected, in particular, with the fact that in the regulations that are in force in Ukraine and in other countries on the calculation of the quality characteristics of the coal preparation products, the expected decrease in sulfur content is not calculated, but only is determined by the previous period. The disadvantage of this method is a significant error in changing the raw material base of coal preparation plants, associated with different ratios of organic and mineral sulfur in the run-of-mine coal of different mines. To acquire the character of a quantitative forecast, the dependences obtained on the basis of laboratory studies with the preparation of coal samples in high-dense liquids need to be clarified taking into account the peculiarities of the practically used technologies of dynamic concentration.

Purpose. Adopted methods for calculating emissions of sulfur dioxide during pulverized combustion, for example, given in the standard of the Ministry of Energy of Ukraine GKD 34.02.305-2002 "Emissions of pollutants into the atmo-

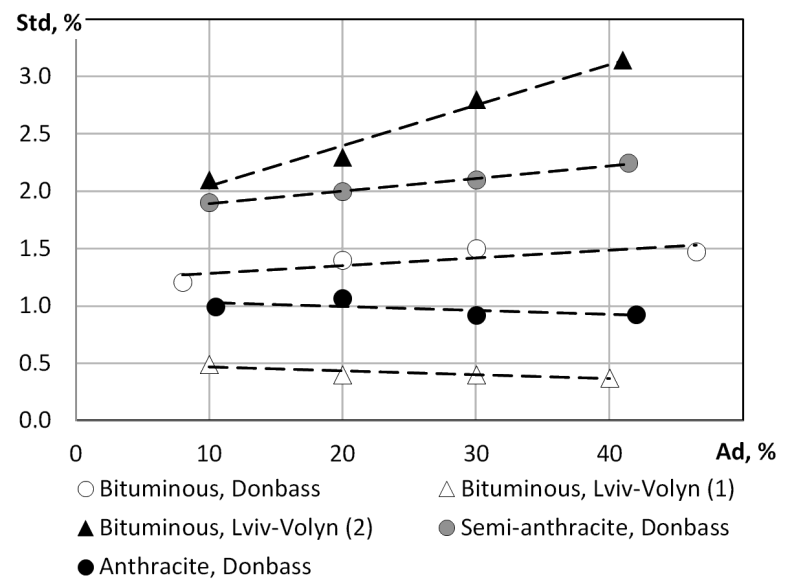

Fig. 2. Dependence of total sulfur content on the ash content of sub-samples of Ukrainian steam coal separated in highdense liquids of different densities [22] sphere from power plants. Methods of determination”, are based on the ratio of sulfur content to the specific volume of dry combustion products, which is calculated on the basis of the elemental composition of the fuel. These methods require ultimate analysis of carbon, hydrogen and oxygen, which is much more complicated and long-term than sulfur analysis, and for which equipment is available in only a small number of coal-chemical laboratories. For simplified estimates of the concentration of $\mathrm{SO}_{2}$ in dry flue gases, the work [23] proposed empirical dependences on the ash content $A^{d}$ and the sulfur content $\mathrm{S}^{d}$ of the fuel drybasis in the form $c_{\mathrm{SO}}=S^{d} \cdot\left(a \cdot A^{d}+b\right)$, where the coefficients a and $\mathrm{b}$ vary depending on the type of coal and method of slag removal, in particular, for the case of combustion of bituminous coal with molten slag removal

$$
c_{\mathrm{SO}_{2}}=S^{d} \cdot\left(1450+32 \cdot A^{d}\right)
$$

Due to the fact that this method is based only on analyses of sulfur content and ash content, which are less complicated and less long-term than ultimate analysis, and equipment for which is available in all coal chemistry laboratories, it can be used as a method of express assessment of forecasted sulfur dioxide emissions when coal combustion. However, in terms of physical content, the specific volume of dry flue gases has a linear dependence not on the ash content, but on the fuel lower heat value, which is reflected only indirectly with the ash content. Even within one grade of coal, there is a significant variation in the LHV value at the same ash and moisture levels, associated with variations in the oxygen and hydrogen content of the fuel. The disadvantage of this method is the lack of accuracy of the forecast determination (for coal of individual deposits, the error of the forecast determination of sulfur dioxide concentration in exhaust gases can be $10 \%$ or more), which requires the development of other simple, but more accurate express methods.

Methods. The study on the features of changes in sulfur content during coal preparation is based on the method of calculating the expected ash content of the concentrate, given in the standard of the Ministry of Energy of Ukraine SOU 10.1.00185755.002-2004 "Coal preparation products. Methodology for calculating quality indicators". It consists of taking a sample of run-of-mine coal, removal of prepared machine size class from the sample, separating it in high-dense liquids into rock fraction (for bituminous coal density is greater than $1800 \mathrm{~kg} / \mathrm{m}^{3}$ ) and rock-free substance (for bituminous coal density is less than $1800 \mathrm{~kg} / \mathrm{m}^{3}$ ), analysis of the ash content of each fraction and the estimated determination of the ash content of the concentrate, taking into account the normalized value of the allowable content of high-dense fractions in the concentrate. In particular, for the most common case of coal preparation in jigging machines with the yield of two products - concentrate and waste (rock)

$$
A_{k}^{d}=\left(\gamma_{h(c)} \cdot A_{h . f .}^{d}+\left(100-\gamma_{h(c)}\right) \cdot A_{l . f .}^{d}\right) / 100,
$$

where $A_{h . f .}^{d}, \quad A_{l . f}^{d}, \%$ are ash content of high-dense and lowdense fraction, accordingly; $\gamma_{h(c)}, \%$ - allowable content of the high-dense fraction in the concentrate (normalized value, Table 1).

In practice, $0-13$ and $0-100 \mathrm{~mm}$ classes, which are previously removed from run-of-mine coal by dry screening, are mainly subjected to preparation by jigging to obtain an energy product. When jigging preparation, the slime fractions and class $0-1 \mathrm{~mm}$ are washed, then concentrated in a settling tank or in hydrocyclones, and after mechanical drying are mixed with a concentrate of $1-13$ or $1-100-\mathrm{mm}$ class. The standard stipulates that in the case of mixing with concentrate of slime or any other product, the average ash content is defined as an average weighted value taking into account the amount and ash content of the products being mixed.

The analysis of the standard method showed that all its provisions for the calculation of the expected ash content 
Table 1

Normalized values of the allowable content of the extraneus fractions

\begin{tabular}{|l|c|c|}
\hline $\begin{array}{c}\text { Washability } \\
\text { category* }\end{array}$ & $\begin{array}{c}\text { Allowable content of } \\
\text { the high-dense } \\
\text { fraction in the } \\
\text { concentrate } \gamma_{h(c)}, \%\end{array}$ & $\begin{array}{c}\text { Allowable content of } \\
\text { the low-dense } \\
\text { fraction in waste } \\
\gamma_{(w)}, \%\end{array}$ \\
\hline Coarse machine class of bitumenous coal larger than $13(25) \mathrm{mm}$ \\
\hline Easy & 3.0 & 1.0 \\
\hline Medium & 3.5 & 1.5 \\
\hline Difficult & 4.0 & 2.0 \\
\hline Very difficult & 5.0 & 2.5 \\
\hline \multicolumn{2}{|c|}{ Fine machine class of bituminous coal with the size from $0.5(1.0)$} \\
to $13(25) \mathrm{mm}$
\end{tabular}

* Ukrainian steam coal belongs mostly to the medium washability category

are valid for the calculation of the expected sulfur content. This is ensured by the fact that the generalized sample, taken from run-of-mine coal in accordance with the current standards for mechanized and manual sampling, accurately reflects its average quality, including the content of total sulfur in the coal as a whole, in the machine size class, in its high and low-dense fractions, and hence in the concentrate, where the low-dense fraction and the normalized portion of the high-dense fraction pass. Based on this, to determine the expected sulfur content in coal preparation products, the method [24] was developed and protected by the patent of Ukraine, which in addition to ash content analytically determines the total sulfur content for each fraction of sample, and the expected total sulfur content in the concentrate is calculated by the formula

$$
S_{c}^{d}=\left(\gamma_{h(c)} \cdot S_{h . f .}^{d}+\left(100-\gamma_{h(c)}\right) \cdot S_{l . f .}^{d}\right) / 100
$$

where $S_{\text {h.f. }}^{d}, S_{l . f .}^{d}, \%$ are total sulfur content in high and lowdense fractions, accordingly; $\gamma_{h(c)}, \%$ - an acceptable content of the high-dense fraction in a concentrate (Table 1). Taking into account the above addition of mechanically dried slime to the concentrate, using the above formula, the yield and sulfur content in the concentrate of class $1-13(1-100) \mathrm{mm}$ should be calculated without taking into account the coal fines of $0-1 \mathrm{~mm}$ and slime, and the same parameters in a mixture of concentrate of class $1-100 \mathrm{~mm}$ with the coal fines and slime should be calculated as an average weighted value.

The study is based on the dependence of sulfurous anhydride emissions from the combustion of steam coal on its quality indicators based on the reference method given in the standard of the Ministry of Energy of Ukraine KGD 34.02.3052002 (ГКД 34.02.305-2002). According to this standard, the concentration of $\mathrm{SO}_{2}$ in dry flue gase, brought into line with the normal conditions and a standard oxygen content of $6 \%$, $c_{\mathrm{SO}_{2}}, \mathrm{mg} / \mathrm{nm}^{3}$, is determined by the formula

$$
c_{\mathrm{SO}_{2}}=1.9 \cdot 10^{4} \cdot S^{r} /\left(1.4 \cdot v_{f g}^{o}\right),
$$

where $Q_{i}^{r}-\mathrm{LHV}, \mathrm{MJ} / \mathrm{kg} ; v_{f g}^{o}=0.01 \cdot\left(1.866 \cdot \varepsilon \cdot C^{r}+0.7 \cdot S^{r}+\right.$ $\left.+0.8 N^{r}\right)+v_{\mathrm{N}_{2} \text { air }}, \mathrm{nm}^{3} / \mathrm{kg}$ is specific volune of the flue gase; $\varepsilon=$ $=0.99-0.995$ is the degree of oxidation of fuel carbon; $v_{\mathrm{N}_{2} \text { air }}=3.762 \cdot v_{\mathrm{O}_{2}}, \mathrm{~nm}^{3} / \mathrm{kg}$ is the specific volume of nitrogen in the air, stoichiometrically required for combustion; $v_{\mathrm{O}_{2}}=0.01 \cdot\left(1.866 \cdot \varepsilon \cdot C^{r}+5.56 \cdot H^{r}+0.7 \cdot S^{r}-0.7 \mathrm{O}^{r}\right), \quad \mathrm{nm}^{3} / \mathrm{kg}$ is the specific volume of oxygen in the air, stoichiometrically required for combustion; $\mathrm{C}^{r}, \mathrm{H}^{r}, \mathrm{~S}^{r}, \mathrm{O}^{r}, \mathrm{~N}^{r}-$ mass fraction of carbon, hydrogen, sulfur, oxygen and nitrogen in coal expressed on as-receieved basis, $\%$. The accuracy of this method is determined by the accuracy of the analysis of the total sulfur content, the allowable relative error is from $5 \%$ at the $\mathrm{S}^{r}=1$ to $1.25 \%$ when $\mathrm{S}^{r}=4 \%$.

Since the sulfur dioxide emissions are inversely proportional to the specific volume of dry flue gase, which, in turn, is directly proportional to the calorific value of the fuel $Q_{i}^{r}$, this work investigates the dependency of the $\mathrm{SO}_{2}$ concentration in dry flue gases on the value of the specific sulfur $\mathrm{S}^{s p}=\mathrm{S}^{r} / Q_{i}^{r}, \% \times \mathrm{kg} /$ Mcal for products of Ukrainian mines and coal preparation plants of bituminous grade. For this purpose, data on the elemental composition of the fuel and LHV from 74 certificates of quality, genetic and technological properties of the fuel were used, which for Ukrainian mines are issued by a specialized laboratory once every 4 years, for coal preparation plants - once a year. The results shown in Fig. 3 certify that this dependence is linear with an approximation factor of 0.99

$$
c_{\mathrm{SO}_{2}}=\left(S_{t}^{r} / Q_{i}^{r}\right) \cdot 12115+197.44 \text {. }
$$

This means that $\mathrm{SO}_{2}$ emissions when prepared coal combustion are reduced not only by a decrease in total sulfur content, but also by an increase in LHV; in the general case, the $\mathrm{SO}_{2}$ emission when combustion of the concentrate decreases even when the total sulfur content during coal preparation does not change or increases. Based on these results, the method [25] was developed and protected by the patent of Ukraine for express determination of the forecasted level of the sulfurous anhydride emissions when pulverized coal combustion by the amount of specific sulfur.

Results. The study investigated bituminous coal from 5 mines of the Lviv-Volyn basin, which is delivered to "Chervonohradska" preparation plant and differs in ash content and sulfur content. The characteristics of run-of-mine fuel of 0 $100 \mathrm{~mm}$ size are given in the first part of Table. 2. The generalized samples were divided into samples of different sizes (from $1-3$ to $50-100 \mathrm{~mm}$ ), each sample was divided in dense liquids into fractions with a density of -1500 (rock-free mass), 15001800 (the so-called middling product mainly consisting of carbonaceous mineral splices) and $+1800 \mathrm{~kg} / \mathrm{m}^{3}$ (rock), and the yield, ash content and total sulfur content were determined for each fraction. The size class $0-1 \mathrm{~mm}$, including slime washed from the classes of larger size, was analyzed separately. The main difference from the research $[5,19,20]$ was that the run-of-mine fuel was not crushed, which corresponded to the conditions of the $1-100 \mathrm{~mm}$ size class coal preparation by jigging, and the size classes available in the run-of-mine coal were distinguished.

The example of the results for Stepova mine is presented in Fig. 4. It can be seen that for all size classes the ash content

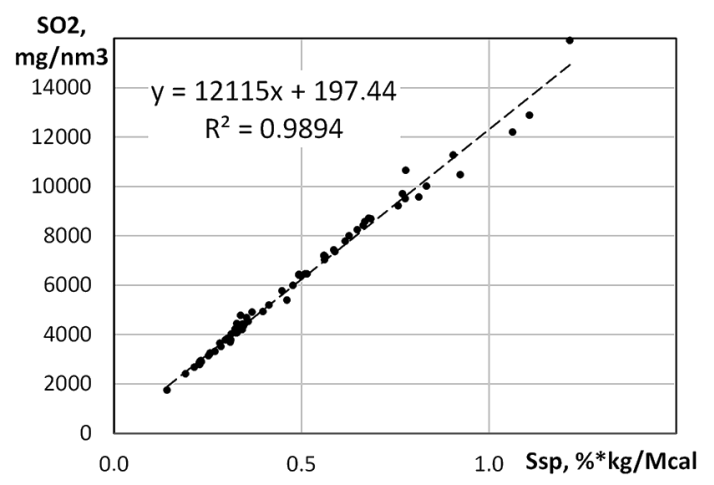

Fig. 3. Dependence of $\mathrm{SO}_{2}$ emission during combustion of bituminous coal of Ukrainian producers on the value of specific sulfur $\mathrm{S}^{s p}$ 
Table 2

Indicators of quality and expected emission of sulfur dioxide when pulverized combustion of the run-of-mine coal and concentrate

\begin{tabular}{|c|c|c|c|c|c|}
\hline Mine & $\begin{array}{l}\frac{\pi}{0} \\
\frac{0}{0} \\
\ddot{\tilde{n}}\end{array}$ & 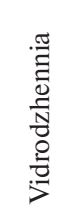 & 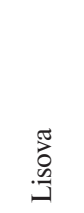 & 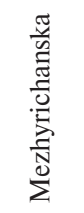 & 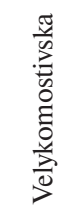 \\
\hline \multicolumn{6}{|c|}{ Run-of-mine coal (class $0-100 \mathrm{~mm}$, analytical data) } \\
\hline$W_{t}^{r}, \%$ & 6.5 & 4.3 & 3.7 & 4.5 & 4.7 \\
\hline$A^{d}, \%$ & 41.60 & 35.90 & 22.40 & 33.00 & 49.20 \\
\hline$S^{d}, \%$ & 2.50 & 2.10 & 2.70 & 6.50 & 1.80 \\
\hline LHV, $\mathrm{kcal} / \mathrm{kg}$ & 4065 & 4676 & 5905 & 4920 & 3488 \\
\hline $\mathrm{S}^{s p}, \% \times \mathrm{kg} / \mathrm{Mcal}$ & 0.575 & 0.420 & 0.427 & 1.235 & 0.483 \\
\hline $\mathrm{SO}_{2}, \mathrm{mg} / \mathrm{nm}^{3}$ & 7164 & 5285 & 5377 & 15163 & 6046 \\
\hline \multicolumn{6}{|c|}{ Concentrate (class $0-100 \mathrm{~mm}$, calculated data) } \\
\hline Yield, $\%$ & 65.5 & 62.6 & 84.6 & 73.2 & 56.4 \\
\hline$W_{t}^{r}, \%$ & 12.0 & 12.0 & 12.0 & 12.0 & 12.0 \\
\hline$A^{d}, \%$ & 17.9 & 16.17 & 11.79 & 16.17 & 20.93 \\
\hline$S^{d}, \%$ & 2.47 & 1.53 & 2.07 & 4.37 & 1.80 \\
\hline LHV, $\mathrm{kcal} / \mathrm{kg}$ & 5713 & 5851 & 6205 & 5851 & 5465 \\
\hline $\mathrm{S}^{s p}, \% \times \mathrm{kg} / \mathrm{Mcal}$ & 0.381 & 0.230 & 0.294 & 0.657 & 0.290 \\
\hline $\mathrm{SO}_{2}, \mathrm{mg} / \mathrm{nm}^{3}$ & 4813 & 2982 & 3758 & 8157 & 3712 \\
\hline
\end{tabular}

monotonically increases with the density according to approximately the same law. Also for all size classes, the total sulfur content in the rock is slightly higher than in the rock-free mass. The middling product has the highest sulfur content; this certifies that most of the pyrite inclusions are concentrated in the splices. However, due to the fact that the yield of the middling product is much lower than that of the rock-free substance and rock mass, it does not make a significant contribution to sulfur content in the run-of-mine coal, which is an intermediate between this one in the rock-free substance and rock.

The yield, ash content and total sulfur content in the class of $0-1 \mathrm{~mm}$, including slime, and in different fractions of the class of 1-100 $\mathrm{mm}$ for all 5 mines are presented in Fig. 5. The above mentioned regularities are valid for all mines; only in the coal of Mezhyrichanska mine, which differs in the extremely high total sulfur content due to the mineral one, the sulfur content in the rock is almost the same as in the splices. It is also seen that the sulfur content in the class of $0-1 \mathrm{~mm}$ approximately coincides with its content in the run-of-mine coal; since the yield of this class is almost a third part of the yield of the rock-free substance of the class $1-100 \mathrm{~mm}$, it significantly affects the ash content and sulfur content of the final concentrate to which it is mixed.

Table 2 shows the quality indicators of the run-of-mine fuel of class $0-100 \mathrm{~mm}$ and quality indicators of the concentrate of the same size class calculated by the developed method (moisture content of $12 \%$ is taken basing on the average indicators of the plant). According to these indicators and the higher heat values on dry ash-free basis known from the coal certificates of each mine, the LHV values for the run-of-mine fuel and concentrate are calculated. Here are also the values of specific sulfur and $\mathrm{SO}_{2}$ concentration in flue gase when pulverized combustion, calculated by the developed method.

Although the operating conditions of the Chervonohradska plant equipment did not allow carrying out many-hour balance tests with stable quality of the run-of-mine coal, the "instant photos" at the entrance and the exit of the jigging section showed the following. Coal from the Stepova mine: the runof-mine coal - ash content $42-46 \%$, sulfur content $2.5-$

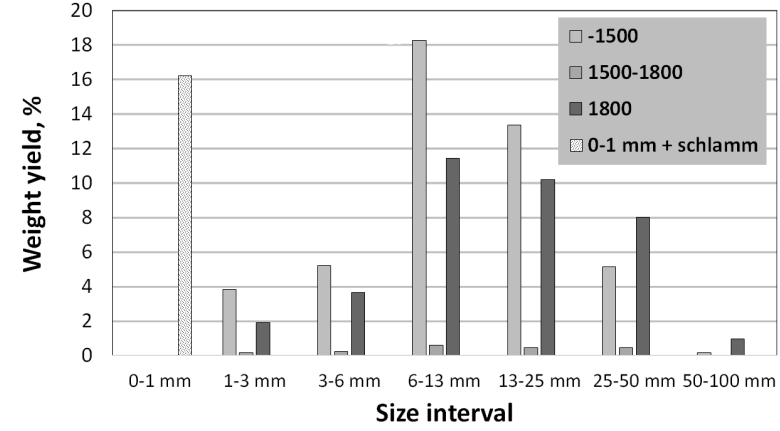

$a$

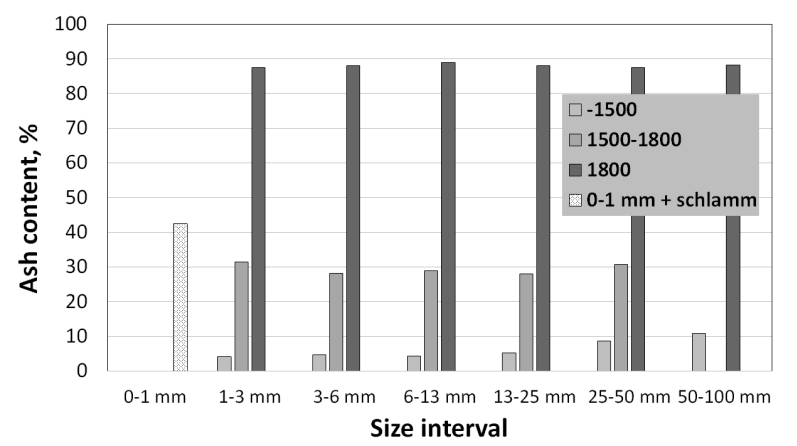

$b$

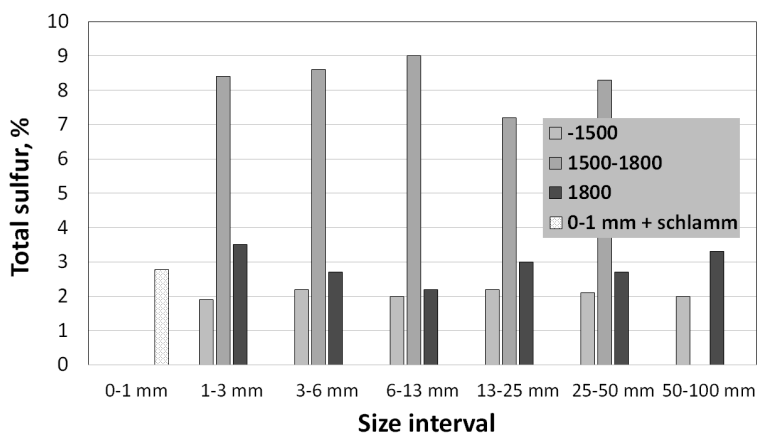

$c$

Fig. 4. Yield (a), ash content (b) and total sulfur content (c) in the coal fractions of different sizes and density of Stepova mine

$2.6 \%$; concentrate $-18-22$ and $2.4-2.5 \%$, respectively; coal from the Velykomostivska mine: the run-of-mine coal - ash content $48-52 \%$, sulfur content $1.8-1.9 \%$; concentrate $21-24$ and $1.8 \%$, respectively. These data confirm the reliability of the calculation of the expected quality indicators of the concentrate and the applicability of the developed method for calculating the expected sulfur content in it.

Table 2 data prove that even in cases when the content of total sulfur in the concentrate does not decrease compared to the run-of-mine coal due to the high content of organic sulfur (for example, Stepova, Velykomostivska mines), the value of $\mathrm{S}^{s p}$ in the concentrate decreases in all cases due to the increase in LHV and, accordingly, the value of $\mathrm{SO}_{2}$ emissions decreases when its combustion.

As it was mentioned above, due to the fact that the yield of the middling product is much lower than the rock-free substance and rock, it does not make a significant contribution to the sulfur content in the run-of-mine fuel. The same is inherent to the concentrate. The most interesting scientific result of the study is the proximity of the sulfur content to the linear dependence on the ash content of the run-of-mine fuel, rockfree substance, rock and concentrate ascertained for all mines (Fig. 6). This makes it possible to forecast the quality of the concentrate not only under regulatory conditions of the coal preparation, i.e., in the case of jigging - when the baffle plate 


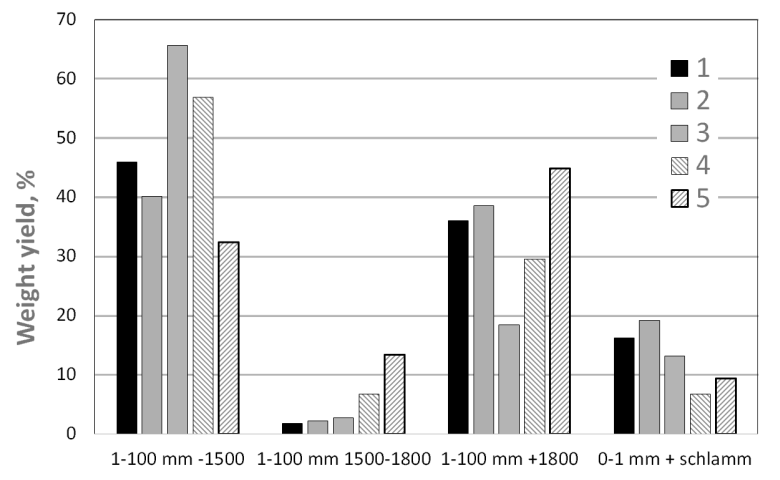

$a$

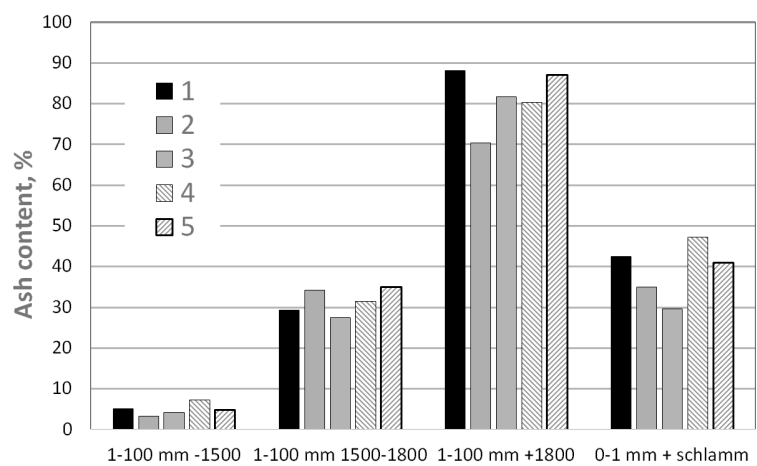

$b$

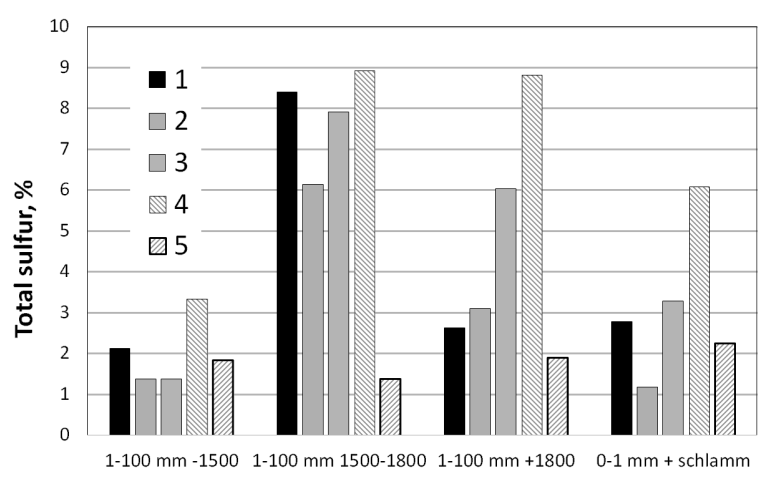

$c$

Fig. 5. Yield (a), ash content (b) and total sulfur content (c) in class $0-1 \mathrm{~mm}$ and in different density fractions of $1-100 \mathrm{~mm}$ class of coal of the mines:

1-Stepova; 2 -Vidrodzhennia; 3 - Lisova; 4-Mezhyrichanska; 5 -Velykomostivska

is located in the jigging bath strictly between the zone of deposition of low and high-dense fractions, but also when adjusting the ash content in the concentrate by replacing the baffle, with the achievement of the LHV value of concentrate, optimal for boilers (in particular, for existing boilers of TPPs in Ukraine, which combust bituminous coal - at the level of $5100-$ $5600 \mathrm{kcal} / \mathrm{kg}$ ).

Based on the ascertained regularity, Table 3 shows the calculations of the sulfur content, LHV, the value of $S^{s p}$ in the concentrate and the emission of the sulfurous anhydride at different depth of the studied coal cleaning, i.e., at different ash content of the concentrate. In all cases, the moisture content of the concentrate was taken as $12 \%$.

Table 3 data show that the studied coal, and in a broad sense - steam bituminous coal of Ukrainian deposits, in terms of the possibility of reducing $\mathrm{SO}_{2}$ emissions through coal preparation can be divided into 3 groups.

The first group includes coal, the preparation of which enables to achieve a level of $\mathrm{SO}_{2}$ emissions that does not exceed the current

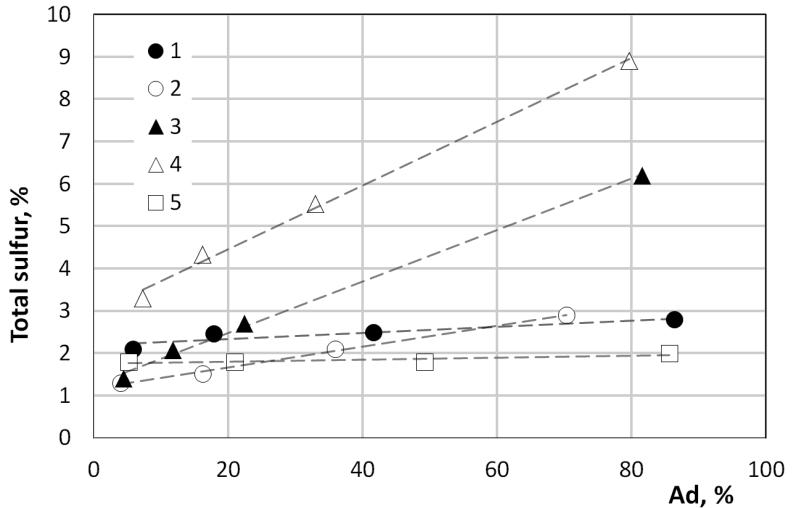

Fig. 6. Dependence of the total sulfur content on ash content (in ascending order of ash content - rock-free substance, concentrate, run-of-mine coal and rock) for different mines. Designation of mines - as in Fig. 5

standard of Ukraine for anthracite combustion of $3400 \mathrm{mg} / \mathrm{nm}^{3}$ (Vidrodzhennia mine at $A^{d} \leq 21 \%$, Velikomostivska mine at $A^{d} \leq$ $18 \%$ ). At this depth of coal cleaning, the LHV of the concentrate will reach $5500 \mathrm{kcal} / \mathrm{kg}$, which ensures the operation of boilers with molten slag removal in a wide range of load control. Concentrates of this coal with such ash content should be used at the anthracite boilers converted to the combustion of bituminous coal without changing the current permits for $\mathrm{SO}_{2}$ emissions [1].

The second group includes coal, the preparation of which enables to achieve a level of $\mathrm{SO}_{2}$ emissions that does not exceed the current standard for bituminous coal burning $5100 \mathrm{mg} / \mathrm{nm}^{3}$ (Stepova mine at $A^{d} \leq 21 \%$, Lisova mine at $\left.A^{d} \leq 19 \%\right)$. At this depth of coal cleaning, the LHV of the concentrate will also reach $5500 \mathrm{kcal} / \mathrm{kg}$. Concentrates of this coal should be used in boilers having bituminous coal as the designed fuel - this is about half of the total number of boilers at TPPs and CHPs of Ukraine.

The third group includes coal, which due to the sulfur content in the rock-free substance of more than 3.3-3.5\% can not be brought to environmentally friendly quality, even if coal is cleaned to an ash content of $15 \%$ (mine Mezhyrichanska). Coal cleaning to lower ash content with a corresponding decrease in the amount of specific sulfur is technically possible, but economically unjustified due to significant losses of com-

Table 3

The sulfur content in the concentrate and $\mathrm{SO}_{2}$ emissions when its combustion depending on the ash content

\begin{tabular}{|l|c|c|c|c|c|}
\hline \multirow{2}{*}{ Mine } & $\begin{array}{c}A^{d}, \\
\%\end{array}$ & $\begin{array}{c}S^{d}, \\
\%\end{array}$ & $\begin{array}{c}\mathrm{LHV}, \\
\mathrm{kcal} / \mathrm{kg}\end{array}$ & $\begin{array}{c}\mathrm{S}^{s p}, \\
\% \cdot \mathrm{kg} / \mathrm{Mcal}\end{array}$ & $\begin{array}{c}\mathrm{SO}_{2}, \\
\mathrm{mg} / \mathrm{nm}^{3}\end{array}$ \\
\hline \multirow{5}{*}{ Stepova } & 30 & 2.49 & 4731 & 0.462 & 5800 \\
\cline { 2 - 6 } & 25 & 2.48 & 5136 & 0.425 & 5347 \\
\cline { 2 - 6 } & 20 & 2.48 & 5540 & 0.393 & 4960 \\
\hline Vidrodzhennia & 30 & 1.93 & 4731 & 0.359 & 4547 \\
\cline { 2 - 6 } & 25 & 1.79 & 5136 & 0.306 & 3903 \\
\cline { 2 - 6 } & 20 & 1.64 & 5540 & 0.260 & 3353 \\
\hline Lisova & 30 & 3.15 & 4731 & 0.586 & 7296 \\
\cline { 2 - 6 } & 25 & 2.85 & 5136 & 0.489 & 6122 \\
\cline { 2 - 6 } & 20 & 2.56 & 5540 & 0.406 & 5120 \\
\hline Mezhyrichanska & 25 & 4.96 & 5136 & 0.850 & 10499 \\
\cline { 2 - 6 } & 20 & 4.61 & 5540 & 0.732 & 9062 \\
\cline { 2 - 6 } & 15 & 4.25 & 5945 & 0.629 & 7821 \\
\hline Velykomostivska & 30 & 1.82 & 4731 & 0.338 & 4292 \\
\cline { 2 - 6 } & 25 & 1.81 & 5136 & 0.311 & 3964 \\
\cline { 2 - 6 } & 20 & 1.81 & 5540 & 0.288 & 3684 \\
\hline
\end{tabular}


bustible substance with waste, and the use of concentrate with LHV over $5600 \mathrm{kcal} / \mathrm{kg}$ enhances the risk of spontaneous explosion in existing pulverizing systems with intermediate dust bins. However, this does not mean that it is impossible to use such coal at TPPs and CHPs in Ukraine. For example, when combusting Mezhyrichanska mine concentrate with $A^{d}=19 \%$ $\mathrm{SO}_{2}$ emissions reach $8800 \mathrm{mg} / \mathrm{nm}^{3}$, but when combusting it in a mixture with the concentrate of the same ash content from the mine Vidrodzhennya in the ratio $1: 2-$ it will not exceed $5085 \mathrm{mg} / \mathrm{nm}^{3}$, which corresponds to current regulations for TPPs designed for bituminous coal combustion. The gradual reduction of $\mathrm{SO}_{2}$ emissions foreseen in the "National Emissions Reduction Plan" for concentrates of the third group can be ensured by mixing with low-sulfur fuels, for example, with Kuzbass coal with a sulfur content of $0.3-0.5 \%$.

Thus, on the basis of the developed methods for determining the expected sulfur content in coal preparation products and express determination of the predicted level of sulfur dioxide emissions during pulverized combustion, for each domestic producer of steam coal it is possible to develop recommendations for an optimal depth of coal preparation and a field of the concentrate application.

Conclusions. The distribution of the sulfur content of Ukrainian steam coal by size classes depending on the ash content was investigated. Based on the obtained results, a method was developed to calculate the expected sulfur content in the concentrate when coal preparation by jigging, taking into account the allowable content of high-dense fraction in the concentrate and the addition of condensed slime to the coal preparation products. A linear dependence of the sulfur content on the ash content of the run-of-mine coal, rock-free substance, rock and concentrate was ascertained for the first time for the technology of coal preparation by jigging. The calculations of the level of sulfurous anhydride emissions during pulverized combustion of coal and its preparation products were performed, taking into account their elemental composition, and the linear dependence of the level of $\mathrm{SO}_{2}$ emissions on the ratio of total sulfur content to the coal lower heat value was proved. Based on the obtained results, the method for determining the predicted level of $\mathrm{SO}_{2}$ emissions when coal combustion was developed, the optimal depth for cleaning coal of different mines of Lviv-Volyn basin was determined by the criterion of correspondence of the LHV to technological requirements and of the level of sulfurous anhydride emissions - to the current environmental standards of Ukraine for pulverized coal boilers. Recommendations for the optimal depth of coal cleaning and for the field of application of the coal concentrate with the different content of total and organic sulfur have been developed.

Acknowledgment. The authors are grateful to Olena Rudavina, the Director of the Ukrainian Research and Design Institute for Coal Preparation and Briquetting (SD "UKRNDIVUHLEZBAHACHENNIA"), for assistance in performing coal analyses and for helpful participation in the discussion.

\section{References.}

1. Chernyavskyy, M.V., Dunayevska, N. I., Provalov, O.Yu., \& Miroshnichenko, Ye. S. (2020). Scientific basis and technologies of anthracite replacement at thermal power plants. Naukovyi Visnyk Natsionalnoho Hirnychoho Universytetu, (3), 33-40. https://doi.org/10.33271/nvngu/2020-3/033.

2. National Emissions Reduction Plan for Large Combustion Plants. Adopted by the direction of Cabinet of Ministers of Ukraine of 08.11.2017 No. 796-r. Retrieved from https://zakon.rada.gov.ua/laws/show/796-2017-\%D1\%80\#Text.

3. Hower, J. (2016). Coal. In Kirk-Othmer Encyclopedia of Chemical Technology, John Wiley \& Sons. https://doi.org/10.1 002/0471238961.0315011222151818.a01.pub3.

4. Speight, J. G. (2013). The Chemistry and Technology of Coal. ( $3^{\text {rd }}$ ed.) CRC Press, Taylor \& Francis Group, Boca Raton, Florida. https://doi.org/10.1201/b12497.
5. Keppeler, J. G. (2015). Coals, Lignite, and Peat. In Kutz, M. (Ed.) (2015). Mechanical Engineers' Handbook, Fourth Edition. JohnWiley\&Sons, Inc. https://doi.org/10.1002/9781118985960. meh420.

6. Kizilshtein, L. Ya. (1975). Genesis of sulfur in coals. Rostov na Donu: Publishing House of Rostov State University.

7. Dolgiy, V.Ya., Krivchenko, A. A., \& Shamalo, M. D. (2000). The content of total sulfur in coal seams in the mines of Ukraine. Coal of Ukraine, (1), 10-12. Retrieved from http://masters. donntu.org/2009/feht/semkovskiy/library/article9.htm.

8. Calkins, W. H. (1994). The chemical forms of sulfur in coal: a review. Fuel, 73(4). 475-484. https://doi.org/10.1016/00162361(94)90028-0.

9. Shpirt, M. Ya., Kler, V. R., \& Pertsikov, I.Z. (1990). Inorganic components of solid fuels. Moscow: Chemistry. ISBN 5-72450578-9.

10. Sidorovych, Ya.Y., Haivanov, V.I., Pishchiev, S.V., Sipyak, O. I., \& Sidorovych, M. Ya. (1997). Problems of desulfurization of coal and utilization of coal sulfur. Coal of Ukraine, (2-3), 16-27.

11. Demirbas, A., \& Balat, M. (2004). Coal Desulfurization via Different Methods. Energy Sources, 26(6), 541-550. https://doi.org/10.1080/00908310490429669.

12. Wang, M., Song, D., Zheng, B., \& Finkelman, R. B. (2008). The Studying of Washing of Arsenic and Sulfur from Coals Having Different Ranges of Arsenic Contents. Annals of the New York Academy of Sciences, 1140(1), 321-324. https:// doi.org/10.1196/annals.1454.018.

13. Bogenschneider, B., Jung, R. G., \& Klein, J. (2005). Desulfurization of Coal. In Biopolymers Online: Biology, Chemistry, Biotechnology, Applications. Part 1. Lignin, Humic Substances and Coal. Wiley-VCH Verlag GmbH. https://doi. org/10.1002/3527600035.bpol1015.

14. Zhang, B., Zhao, Y., Zhou, Ch., Duan, Ch., \& Dong, L. (2015). Fine Coal Desulfurization by Magnetic Separation and the Behavior of Sulfur Component Response in Microwave EnergyPretreatment. EnergyandFuels, 29(2):150109100223007. https://doi.org/10.1021/ef502003g.

15. Zhang, B., Zhou, C., Zhao, Y., Cai., L., \& Fan, X. (2017). Fine coal desulphurization and microwave energy absorption behaviour by microwave magnetic separation. The Canadian Journal of Chemical Engineering, 95, 1156-1163. https://doi. org/10.1002/cjce.22769.

16. Laptienko, A. L., Rekun, V.V., Taryanik, A.V., Saranchuk, V. I., \& Shendrik, T. G. (2003). Method of deep purification of coal and coal wastes from ash and sulfur. Coke and chemistry, (8), 14-18.

17. Merkhut, A., \& Tymoschuk, M. (2019). Modernization of coal mills using the "HER-ART" technology, a method of extending the service life and reducing emissions. $15^{\text {th }}$ International scientific-practical. conf. "Coal thermal energy: ways of reconstruction and development": Collection of Science works, (pp. 85-88). Kyiv: IVE NAS of Ukraine.

18. Chiang, S. H., \& Cobb, J. T. (2000). Coal Conversion Processes, Cleaning and Desulfurization. In Kirk-Othmer Encyclopedia of Chemical Technology. John Wiley \& Sons. https:// doi.org/10.1002/0471238961.0312050103080901.a01.

19. Cavallaro, J.A., Deurbrouck, A.W., Killmeyer, R.P., Fuchs, W., \& Jacobsen, P. S. (1991). Sulfur and Ash Reduction Potential and Selected Chemical and Physical Properties of United States Coals. DOE/PETC-91/6. Retrieved from https:// www.osti.gov/servlets/purl/5435690.

20. Ali, A., Srivastava, S. K., \& Haque, R. (1992). Studies on the Simultaneous Desulphurization and Demineralization of Coal. Fuel, 71, 835-839.

21. Speight, J. G. (2013). Recovery, Preparation, and Transportation. In Coal-Fired Power Generation Handbook, (pp. 69-126). Scrivener Publishing LLC. https://doi. org/10.1002/9781118739457.ch3.

22. Filippenko, Yu.N., Rudavina, E.V., Sklyar, P.T., \& Chernyavsky, N. V. (2010). The contribution of mineral mass 
to the observed values of the volatile yield and the elemental composition of coal. Enrichment of minerals: scientific and technical collection, 40(81), 26-31. Retrieved from http://ir. nmu.org.ua/bitstream/handle/123456789/152686/6. pdf? sequence $=1 \&$ isAllowed $=\mathrm{y}$.

23. Volchin, I.A., \& Gaponich, L.S. (2016). Calculation of parameters of flue gases of coal thermal power plants on the basis of characteristics of solid fuel. Energy technologies and resource saving, (1), 49-56.

24. Chernyavskyy, M.V. (2020). The method of determining the expected sulfur content in the coal preparation products. (Ukrainian Patent No. 143011). Ukraine.

25. Chernyavskyy, M.V., Dulienko, S.G., \& Monastyreva, T. M. (2020). The method of express determination of predicted level of sulfur dioxide emissions when pulverized combustion of bituminous coal. (Ukrainian Patent No. 143014). Ukraine.

\section{Прогнозування зміни вмісту сірки при збагаченні енергетичного вугілля та рівня викидів сірчистого ангідриду при його спалюванні}

\section{М. В. Чернявський ${ }^{1}$, А. М. Воронов ${ }^{2}$, О. В. Моісеєнко ${ }^{2}$, С. Г. Дулієнко ${ }^{1}$, Т. М. Монастирьова ${ }^{1}$}

1 - Інститут вугільних енерготехнологій НАН України, м. Київ, Україна, e-mail: ceti@i.kiev.ua

2 - Відокремлений підрозділ «Український науково-дослідний і проектно-конструкторський інститут по збагаченню та брикетуванню вугілля» державного підприємства «Науково-технічний центр «ВУГЛЕІННОВАЦІЯ», м. Дніпро, Україна

Мета. Розроблення методу та прогнозної оцінки зниження викидів сірчистого ангідриду при спалюванні енергетичного вугілля за рахунок регулювання його якості при збагаченні.

Методика. Дослідження вмісту сірки у вугіллі з використанням ситового, фракційного аналізу, аналізу зольності та вмісту загальної сірки. Прогнозування вмісту сірки в концентраті за розробленим розрахунковим методом. Промислові випробування на збагачувальній фабриці. Прогнозування рівня викидів $\mathrm{SO}_{2}$ при пиловидному спалюванні вугілля за розробленим розрахунковим методом.

Результати. Досліджено розподіл вмісту сірки по класах крупності українського енергетичного бітумінозного вугілля в залежності від зольності, доведена близькість до лінійної залежності вмісту сірки від зольності вихідного вугілля, безпородної маси, породи й концентрату. Виконані розрахунки рівня викидів $\mathrm{SO}_{2}$ при пиловидному спалюванні вугілля та продуктів його збагачення з урахуванням їх елементного складу та доведена лінійна залежність рівня викидів $\mathrm{SO}_{2}$ від відношення вмісту загальної сірки до нижчої теплоти згоряння (LHV). На підставі одержаних результатів розроблені способи визначення очікуваного вмісту сірки в концентраті та прогнозного рівня викидів $\mathrm{SO}_{2}$ при його спалюванні, визначена оптимальна глибина збагачення для вугілля різних шахт за критерієм відповідності рівня викидів $\mathrm{SO}_{2}$ чинним екологічним нормам.

Наукова новизна. Доведена близькість до лінійної залежності вмісту сірки від зольності вихідного вугілля, безпородної маси, породи й концентрату. Доведена лінійна залежність рівня викидів $\mathrm{SO}_{2}$ від відношення вмісту загальної сірки до LHV при пиловидному спалюванні вугілля та продуктів його збагачення.

Практична значимість. Розроблено спосіб визначення очікуваного вмісту сірки у продуктах збагачення вугілля відсадкою з урахуванням припустимого вмісту важкої фракції в концентраті й додавання згущеного шламу до продуктів збагачення. Розроблено спосіб визначення прогнозного рівня викидів $\mathrm{SO}_{2}$ при ї спалюванні. Визначена оптимальна глибина збагачення для вугілля різних шахт за критерієм відповідності рівня викидів $\mathrm{SO}_{2}$ чинним екологічним нормам.

Ключові слова: енергетичне вугілля, вміст сірки, збагачення, пиловидне спалювання, викиди діоксиду сірки

\section{Прогнозирование изменения содержания серы при обогащении энергетического угля и уровня выбросов сернистого ангидрида при его сжигании}

\section{Н. В. Чернявский, А. Н. Воронов ${ }^{2}$, О. В. Моисеенко ${ }^{2}$,} С. Г. Дулиенко ${ }^{1}$, Т. Н. Монастырева ${ }^{1}$

1 - Институт угольных энерготехнологий НАН Украины, г. Киев, Украина, e-mail: ceti@i.kiev.ua

2 - Обособленное подразделение «Украинский научноисследовательский и проектно-конструкторский институт по обогащению и брикетированию угля» государственного предприятия «Научно-технический центр «УГЛЕИННОВАЦИЯ», г. Днепр, Украина

Цель. Разработка метода и прогнозной оценки снижения выбросов диоксида серы при сжигании энергетического угля за счет регулирования его качества при обогащении.

Методика. Исследование содержания серы в угле с использованием ситового, фракционного анализа, анализа зольности и содержания общей серы. Прогнозирование содержания серы в концентрате разработанным расчетным методом. Промышленные испытания на обогатительной фабрике. Прогнозирование уровня выбросов $\mathrm{SO}_{2}$ при пылевидном сжигании угля разработанным расчетным методом.

Результаты. Исследовано распределение содержания серы по классам крупности украинских энергетических газовых углей в зависимости от зольности, доказана близость к линейной зависимости содержания серы от зольности исходного угля, беспородной массы, породы и концентрата. Выполнены расчеты уровня выбросов $\mathrm{SO}_{2}$ при пылевидном сжигании угля и продуктов его обогащения с учетом их элементного состава и доказана линейная зависимость уровня выбросов $\mathrm{SO}_{2}$ от отношения содержания общей серы к низшей теплоте сгорания (LHV). На основании полученных результатов разработаны способы определения ожидаемого содержания серы в продуктах обогащения угля и прогнозного уровня выбросов $\mathrm{SO}_{2}$ при их сжигании, определена оптимальная глубина обогащения для углей разных шахт по критерию соответствия уровня выбросов $\mathrm{SO}_{2}$ действующим экологическим нормам.

Научная новизна. Доказана близость к линейной зависимости содержания серы от зольности исходного угля, беспородной массы, породы и концентрата. Доказана линейная зависимость уровня выбросов $\mathrm{SO}_{2}$ от отношения содержания общей серы к LHV при пылевидном сжигании угля и продуктов его обогащения.

Практическая значимость. Разработан способ определения ожидаемого содержания серы в продуктах обогащения угля отсадкой с учетом допустимого содержания тяжелой фракции в концентрате и добавления сгущенного шлама к продуктам обогащения. Разработан способ определения прогнозного уровня выбросов $\mathrm{SO}_{2}$ при их сжигании. Определена оптимальная глубина обогащения для углей разных шахт по критерию соответствия уровня выбросов $\mathrm{SO}_{2}$ действующим экологическим нормам.

Ключевые слова: энергетический уголь, содержание серы, обогащение, пылевидное сжигание, выбросы диоксида серы

Recommended for publication by T. G. Shendrik, Doctor of Chemical Sciences. The manuscript was submitted 11.11.20. 